\title{
ДРАГОЦЕННОСТИ РЮРИКОВИЧЕЙ ПО ПИСЬМЕННЫМ ПАМЯТНИКАМ (СТОЛОВАЯ ПОСУДА И ПРИБОРЫ)
}

\section{RURIK DYNASTY HEIRLOOMS ON THE BASIS OF WRITTEN SOURCES (TABLEWARE NAMES)}

\author{
BOŻENA HRYNKIEWICZ-ADAMSKICH
}

\begin{abstract}
Aвstract. The aim of the article is to present the names of the valuables in testaments of the Russian great and appanage princes of the 14-16 c. Special attention has been paid to tableware terminology. Lexicographical and etymological data as well as the semantic classification of the tableware names are provided. Dishes and eating utensils used by the Rurik dynasty members during feasts were made of gold or silver and were extremely decorative. According to Thorstein Veblen, conspicuous consumption and wasteful expenditure were signs of person's high social position. The author draws our attention to the fact that vicarious consumption on the house by invited guests was possible too. Therefore, the social meaning of these valuables is presented in this article.
\end{abstract}

Keywords: testaments of the Russian great and appanage princes, tableware names, the 14-16 c., conspicuous consumption, vicarious consumption

Bożena Hrynkiewicz-Adamskich, Uniwersytet im. Adama Mickiewicza w Poznaniu, Poznań - Polska, bhrynk@amu.edu.pl

ORCID ID: 0000-0002-9589-841X

В Средневековье на Руси не только драгоценные княжеские наряды и украшения ${ }^{1}$, но и столовые приборы, золотая и серебряная посуда, используемые при демонстративном потреблении пищи и напитков, представляли собой важную составную часть движимого имущества Рюриковичей и предмет наследования.

Приступая к анализу названий видов посуды и приборов, засвидетельствованных в духовных грамотах представителей княжеского сословия XIV-XVI столетий [Гр.], стоит обратить внимание на символику и антропологию пищи. Соласно Брониславу Малиновскому [Malinowski 1957: XLIII], уже в примитивных сообществах различные социаль-

${ }^{1}$ Настоящая статья представляет собой вторую часть работы, посвященной анализу названий и социальной семантики драгоценностей, передаваемых из поколения в поколение представителями династии Рюриковичей. В первой части исследовались названия элементов княжеской одежды [Hrynkiewicz-Adamskich 2018]. 
ные нормы регулировали способ распределения добычи и подготовки пищи, а ее потребление имело ритуальный характер. Упомянутый автор утверждает, что питание является одной из двух фундаментальных биологических потребностей человеческого организма, наряду с воспроизводством рода. Поэтому изучение обычаев, связанных с питанием, имеет ключевое значение для понимания человеческой культуры и ее институтов.

Данная проблематика вызывает оживленный интерес исследователей также в настоящее время. Так, по наблюдениям Анджея Марии Кемпиньского [Kempiński 1993: 470-472], пища выполняла роль посредника между природой и культурой, на что указывают такие обычаи, как приветствие прибывшего с хлебом и солью; безвозмездный прием и угощение пищей странников, нивелирующее разницу между „своим” и „чужим”; принятие пищи в местах захоронения умерших в целях объединения живых и покойных; подготовка поминальной трапезы для душ предков. Согласно Николаю Андреевичу Хренову [2008: 273], „связанные с едой и питьем древние представления предполагают, что есть и пить с кем-либо означает принять на себя взаимные обязанности", сродниться друг с другом. Совместное принятие пищи и напитков, в частности алкогольных, оказывало интегрирующее воздействие на участников застолья [Brzozowska-Krajka 1998: 83-84]. При этом обыкновенное застолье служило консолидации семьи, праздничное - объединению членов общины. У русских общие празднования в складчину разного характера назывались братчинами [Терновская, Толстой 1995: 256]. Как правило, участники праздничного застолья ели как можно больше. К праздникам готовилась обильная и разнообразная еда, лучшие блюда и напитки. Особого внимания заслуживают званые пиршества. Их основной целью было обновление связей между хозяином и каждым из приглашенных. Приглашение на застолье являлось знаком благорасположенности хозяина к гостю. По справедливому замечанию Анны Задрожиньской [Zadrożyńska 1988: 61], каждое застолье можно трактовать как акт, с одной стороны, дарения, с другой - принятия подарков, так как всегда в данном случае есть дарители и одариваемые, т.е. те, кто организовал застолье и подготовил пищу, и те, кто был приглашен потреблять ее.

В этой связи напомним, что, по мнению Торстейна Веблена, показное потребление (conspicuous consumption) является одним из главных показателей высокого социального статуса лица, помимо богатства и расточительности (wasteful expenditure). Согласно упомянутому автору [Veblen 2008: 64-65], на ранних стадиях экономического развития общностей не- 
ограниченное потребление, в особенности продуктов лучшего качества, являлось привилегией состоятельных людей, в основном, представителей правящего сословия. Они не только принимали пищу в количестве превышающем норму, обеспечивающую сохранение здоровья, но потребляли специальные сорта продуктов. Веблен обращает также внимание на возможность демонстративного „потребления по доверенности” (vicarious consumption). Во имя хозяина могли потреблять его жена, дети, челядь, дружина, гости, свидетельствуя тем самым в пользу его величия и богатства. В данном случае потребление должно осуществляться таким образом и в такой обстановке, чтобы было ясно, за чей счет оно происходит и кому принадлежит престиж. Согласно Веблену, расточительность и избыточное потребление на средства спонсора являются своего рода инвестицией, которая окупается в виде признания и славы лица, по поручению которого устраивается застолье [Veblen 2008: 68].

Материал изученных духовных грамот позволяет сделать вывод о том, что употребляемые представителями княжеского рода столовая посуда и приборы, подобно парадным княжеским нарядам, отличались очень высоким уровнем исполнения, декоративностью, изысканностью украшений, а в связи с этим высокой стоимостью. Передаваемые по наследству предметы княжеской домашней утвари были в основном изготовлены из:

- серебра, см.:

(3 блюда серъбръна [Гр. 7]; блюдо серебрьно гзздниньскоге (Гр. 7); Восмь иярок серебраных грановитых з золотом [Гр. 350]; суды серебраные, тритиат(в) блюд без одног(о) [Гр. 352]; сковорода серебрена с венцом [Гр. 352]);

- золота, см.:

(2 чашки круглыи золоты [Гр. 7]; 2 чума золота болиап [Гр. 7]; два ковша золоты [Гр. 276]; три чарки зөлюты [Гр. 310]);

- камня, см.:

(каменое судно Велико [Гр. 61]; с8ды мои каменые [Гр. 302]); суды каменые [Гр. 352]);

- хрусталя, См.:

(кубок хрусталнои, что ми король прислал [Гр. 61]).

В анализируемых документах засвидетельствовано употребление разных видов ювелирной техники [см. Словарь ювелирных терминов; Gradowski 1980]:

- чеканка (иначе выколотка), т.е. изготовление рисунка, надписи, изображения посредством выбивания на металлической пластине определенного рельефа, см.:

(кубок чеканен с финифтом серебрен жо золочон, а весу четыре гривенки без деслти золотников [Гр. 406]; оуксусница чеканена на стоганце с рукогад(ъ)ю и с носком [Гр. 412]; ковшь серебранб на чешвю битъ [Гр. 221]; к8бок серебрАнъ на косые грани бит [Гр. 221]); 
- золочение, т.е. нанесение тонкого слоя золота, позолоты, см.:

(кубок с полкою серебрен золочон, а весу полпеты гривенки и восмъ золотников [Гр. 406]; два судна на стогнцех, через гран(в) золочоны, с носки и с верики, а на вершкъх по птице [Гр. 411]; ковшь болшои, венеи, оу нег(о) писан золочон, имА кн(А)зА Михаила Gндрегвича, а на полке птица золочона [Гр. 411]; два ковша венцы писаны золочоны, имм кн(А)зя Ивана Юрьевича, а на полках литы звгори золочоны, а внутри клеина литы звгори золочоны [Гр. 412]);

- литье, т.е. изготовление предметов посредством литья расплавленного металла в форму с последующим охлаждением и затвердеванием, см.:

(ковшь болшои грановит, што мнть дал кнлз(ь) велики Василеи, венеи оу нег(о) писан золочон, имл великог(о) кн(А)зА Васил(ь) га Ивановича Всега Р8си, а на полке литы звьри [Гр. 411]; ковшь болшои, венец, оу нег(о) писан золочон, имх кн(я)зя Бориса Васильевича, а на полке лит звтьрь и оузорь [Гр. 411]; три солоницы, двг солоницы на зверктх с вершки, по оузором писаны и золочоны, а солоница с вериком дълана с өиниөтом скан(ь)ю, золочона, а на неи люди литы [Гр. 412]);

- оковка, т.е. покрытие предмета со всех сторон металлом, обивание металлом, см.:

(дастоканъ и( (а)рьгородскии золотомъ кованъ [Гр. 16]; судно оковано золотом [Гр. 61]);

- клеймение, т.е. нанесение графического изображения на изделиях из металла ударным способом инструментом из более твердого металла, см.:

(два ковиа венцы писаны золочоны, имА кн(А)зА Ивана Юрьевича, а на полках литы звтори золочоны, а внутри клечна литы звтьри золочоны [Гр. 412]; nат(ь) достоканов оуголчатых с вершком же, венцы золочоны, а внутри клеино с өиниөтом, писаны слова [Гр. 413]; четыре чарки с полками, а на полках литы оузоры, а венцы изнутри писаны золочоны, а на днго клеино с өиниөтом писано золочоно, да по три рыбки золочоны [Гр. 413]);

- скань (иначе филигрань), т.е. производство ажурного или напаянного на металлический фон узора в виде веревочки, шнурка, плетения, елочки, дорожки, глади и т.д. из тонкой проволоки (обычно из сплавов золота, серебра, иногда также меди и латуни); в единое целое отдельные элементы скани соединялись при помощи пайки, см.:

(ковшик на стогние венеи золочон, скан(ь)ю дюлан, а на полке нащока скан(ъ)ю же дглана [Гр. 412]; ковшб, венеи писан золочон, имл пана Михаила Кезгаиловича, что мнгь дал княз(ь) Велики Василеи, а полка на четыре оуглы скан(ь)ю делана, а внутри клеино с өиниөтом [Гр. 412]; п九т(ь) достоканов с вершком, шдин на ношках с погаски, скан(в)ю делан, а четыре гладки, венцы золочоны [Гр. 413]);

- финифть, т.е. изготовление художественных произведений с помощью стекловидного порошка, эмали, на металлической подложке, часто сочетаемое со сканью, чеканкой, гравировкой, см.:

(кубок чеканен с финифтом серебрен жо золочон, а весу четыре гривенки без деслти золотников [Гр. 406]; солоница с вершком дълана с өиниөтом скан(ъ)ю, золочона, а на неи люди литы [Гр. 412]; ковшь, венец, писан золочон, имл пана Михаила Кезгаиловича, что мнг дал кнлз(ь) велики Василеи, а полка на четыре оуглы скан(ь)ю дглана, а внутри 
клеино с өиниөтом [Гр. 412]; ковшъ пупчат, а в нем внутри клеино съ өиниөтом, а на клеине зверок шленеи золочон [Гр. 413]; плm(ь) достоканов оуголчатых с вершком же, венцы золочоны, а внутри клеино с өиниөтом, писаны слова [Гр. 413]; м8шорма с носком и с р8когад(ь)ю, венцы и звгори золочоны гладки, а на покрышке въ кр8г8 на өиниөте писано има кн(А)за Дмитрег Ивановича [Гр. 413]);

- инкрустация, т.е. декорирование сосудов жемчугом и драгоценными камнями, врезаемыми в металлическую основу, см.:

(2 чаши золоты с женчуги [Гр. 7]; блюдие золото с женчугомь с каменьємь [Гр. 7]; ковшь золотъ слалом да съ женчюги [Гр. 57]; два ковиика зшльты, бдин с камышком да с жемчюжки [Гр. 311]).

В описаниях нарядных, праздничных сосудов упоминаются утонченные декоративно-пластические элементы:

- городок 'зубец' [СлРЯ XI-XVII вв. 4: 94], см.:

(два судна на стоганиех с р8когдми без носков, а оу шдново судна на вершк8 городок, а оу др8гово на вершк8 птицца [Гр. 411]);

- мишень (м. р.) - 1. 'печать'; 2. 'клеймо'; 3. 'круглая пластинка - резная, чеканная, вышитая или рисованная' [Срезн. II: 155], см.:

(два блюда г8сины, Фдно гладко, а на др8гом четыре мишени, имА великог(о) кн(А)зя Ивана Васил(ь)евича [Гр. 412]; дватияат(ь) мис и бдна миса, на десмти мисах на краех по три мишени, има великог(о) кн(я)за Ивана Васил(ь)евича Всег Р8си, а на шти мисах на краех по мишени, по выбоичатом8, а на дв8 мисах имл Еоуөим(ъ)ево, а на дв8 ж мисах по мишени по литовском8, а миса глад(ка)г [Гр. 412]; перечница с вершком, а вершок на неи скан(ь)ю дглан золочон, а на днғ три мишени золочоны [Гр. 412]);

- мишенец - уменьшит. от мишень [Срезн. II: 156], см.: (сорок и шесть блюд, а на них на краех по мишения по выбоичатомв [Гр. 412]; nАт(ь) блюд, а на них на краех по два мишенияа по выбоччатом8 [Гр. 412]).

На многих предметах повторяются мотивы:

- кружков, напр.:

(десат(ь) блюд, а на них има Великог(о) кн(А)за Ивана Васил(ь)евича Всега Рвси в трех кр8шкпх [Гр. 412]; пат(ь) достоканов, а на них по три свитки, да по три крушки, да вензы золочоны [Гр. 413]; плт(ь) достоканов малых, а на них по три венцы да по кр8шк8 писаны золочоны [Гр. 413]; три чарки ромпики гладки, а на них по четыре крушки, имх кн(я)зя Дмитрег Ивановича [Гр. 413]; двг братины, ито мнть дал кнмз(ь) велики Василеи, а на них по четыре крвики золочоны, а в них писано имл великог(о) кн(я)зя Васил(ь)ево [Гр. 413]);

- поясков, напр.:

(пмт(ь) достоканов с вершком, шдин на ношках с погаски, скан(ъ)ю делан, а четыре гладки, вениы золочоны [Гр. 413]; два достоканиуа, шдин гладок, а оу др8гово на середке погскк золочон [Гр. 413]; двг перечницы на стогниех с вершки, шдна через грань золочона, а др8гага гладкаг, погасок скан(ъ)ю дълан [Гр. 414]; три ж ставиы, оу дв8 погаски писаны золочоны, имА Кн(А) зА ИВана Юрьевича, а оу трет(ъ)еВо погасок писан, а не золочон, имА Кн(А)зн GНндтга Васильевича [Гр. 414]).

Довольно часто встречаются также орнаменты:

- зооморфные, состоящие из стилизованных изображений животных, птиц, рыб, напр.: 
(ковшг болшои грановит, што мнг дал кн(я)з(ь) велики Василеи, венеи, оу нег(о) писан золочон, има великог(о) кн(А)за Васил(ь)га Ивановича всег Р8си, а на полке литы звгори [Гр. 411]; ковшв болшои, венеи оу нег(о) писан золочон, имх кн(А)зн Бориса Васильевича, а на полке лит звгорь и оузорв [Гр. 411]; ковшь болшои, венец оу нег(о) писан золочон, имА КН(А)зА Михаила Gндрегвича, а на полке птица золочона [Гр. 411]; ковшь болшои што мнть дал ег(о) кнлз(ь) велики Василеи, а венеи писан золочон, имл Еоуеөим(b) га вл(а)

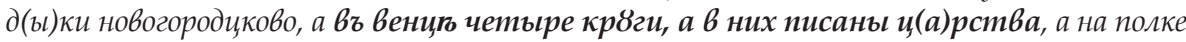
шбразина золочона, а вкруг ег венец на проем золочон, а внутри кружок золочон, $a$ нем три рыбки [Гр. 411]; ковшъ гладок, а на нем четыре крушки, имл Великог(о) кн(я)зн Ивана Васил(ь)евича Всега Р8си, а внутри зверок писан [Гр. 412]; ковшг пупчат, а в нем внутри клеино съ өиниөтом, а на клеине зверок шленеи, золочон [Гр. 413]) ;

- растительные:

(семнатцат(ь) кубков золочоных и не золочоных розных с п8пыши и с травами и достокановым дълом [Гр. 411]).

Как правило, на металлических предметах домашнего обихода, в том числе также на элементах столовой посуды, размещались надписи разного значения:

- коммеморативного, напр.:

(ковшь болшои, венеи, писан золочон, имн великог(о) кн(А)зн Васил(ъ) г Васил(ь)евича [Гр. 411]; деслт(ь) блюд, а на них имл Великог(о) кн(я)зн ИВана Васил(в)евича всег Р8си 8 трех кр8шкґх [Гр. 412]; став пат(ь) ковшов, што мнг дал кназ(ь) велики Василеи, а Венцы оу них писаны, имм Великог(о) кн(А)зм Васил(ь) г Ивановича всег Р8си, а въс8 в них полдр8гонатицаты гривенки и два золотника [Гр. 412]; плт(ь) братинок, а на них венцы, а $\mathbf{b}$ них писано имм кн(А)зя Дмитрег ИВановича, да люди и звгори писаны золочоны [Гр. 413]; Фдиннатцат(ь) чарок гладких, вениы оу них изнутри и на днг писаны золочоны, имл кн(А)зА Васил(ъ)г кн(А)жа Иванова с(ы)на Юръевича [Гр. 413]; сем(ь) ковшов пит(ь)их гладких, да два ковша пит(ь)и гладки, а внутри писаны слова золочоны, имА Михаила Семеновича [Гр. 413]; девАт(ъ) горчишников, семь гладких, а оу дв8 на краех по три мищенцы, а в них писано имл великог(о) кн(А)зи ИВаново [Гр. 414]);

- инвокативного, напр.:

(четыре солоницы на стогниех, оу бдное венец писан золочон, имя великог(о) кн(я)зя Ивана, а оу др8гие венеи писан золочон, а на днг три кр8шки золочоны, а в одном крушк8 писано има кн(А)жо Андргево, а оу дву венцы писаны, а не золочоны, оу шдное имл великог(о) кн(А)зн ИВана, а оу др8гие: „при славе бвди смирен” [Гр. 414]);

- религиозного, напр.:

(ковшг грановит через гран(ь) золочон, венец писан золочон, а писаны слова притча $\omega$ винг, а на полке две рыбки золочоны [Гр. 412]; ковшь гладок, венеи, писан золочон, а писано на нем бл(а)г(о)с(ло)Вен(ь)е г(о)с(под)не, а на полке мишенец выбоччат [Гр. 413]).

Конечно, формы посуды были дифференцированы по назначению. В проанализированных источниках наряду с ее общими названиями засвидетельствованы названия отдельных элементов столовой утвари, приборов, прочих столовых принадлежностей и настольных украшений. 


\section{I. Общие названия посуды}

СУД (СУДЪ) 'сосуд' [Срезн. III: 602]. Из *som- и и.-е. корня *dhe- (деть, дело), ср. лит. ìndas 'сосуд’. Ср. греч. Эท́хฤ 'хранилище' [Фасмер III: 794]

(исъ судов исъ серебрьныхъ [Гр. 7]; из моихъ судовъ из серебрьных [Гр. 8]; суды зол(о) тыль [Гр. 25]; серебреныг суды [Гр. 25]; с8ды мои каменые [Гр. 302]; судов восмь [Гр. 350]; суды серебраные [Гр. 352]; суды каменые [Гр. 352]; с8дов моих в казнљ [Гр. 411]; походных судов [Гр. 412]).

СУДЕНКО ‘небольшой сосуд’ [СлРЯ XI-XVII вв. 28: 256] (суденко сводное золочено [Гр. 406]).

СУДНО 'сосуд, посудина' [СлРЯ XI-XVII вв. 28: 266]. Связано с суд, сосуд, посуда [Фасмер III: 796]

(судно оковано золотом [Гр. 61]; каменое судно велико [Гр. 61]; два судна на стоганиех, через гран(ъ) золочоны, с носки и с верики, а на верикъх по птище [Гр. 411]; два судна на стогннеех с р8когадми без носков, а оу шдново судна на верик8 городок, а оу др8гово на Верик8 птица [Гр. 411]; судно с р8когад(ъ)ю и с носком [Гр. 411]).

\section{II. Названия элементов столовой утвари}

\section{1. Названия посуды, предназначенной для подачи на стол напитков}

БАДЬЯ/БАДИЯ 'сосуд для питья, crater' [Срезн. I: 39]. Заимствовано через тат. badiä, badia из перс. bādye 'сосуд для вина' [Фасмер I: 104] (бадьга серебрена с наливкою серебреною..., с каменьемъ [Гр. 16]).

БРАТИНА/БРАТЕНА/БРАТИМА ' сосуд в форме горшка, в котором подавались напитки' [СлРЯ XI-XVII вв. 1: 321]; 'непременно металлическая, преимущественно золотая и серебряная, заздравная круговая чаша, испиваемая перед принятием пищи как обет сохранения духовного братства' [Вельтман 1860: 115]

(двг братины, итоо мнгъ дал кн(А) з(ъ) Велики Василеи, а на них по четыре кр8шки золочоны, а в них писано има великог(о) кн(А) за Васил(ъ)ево [Гр. 413]).

БРАТИНКА/БРАТЕНКА 'небольшая братина' [СлРЯ XI-XVII вв. 1: 322] (пат(ь) братинок, а на них венцы, а В них писано имл кн(А) за Дмитрега ИВановича, да люди и звтори писаны золочоны [Гр. 413]).

КОВШ (КОВШЪ) 'одноручный сосудец, с рукоятью, для черпания жидкостей, для питья' [Даль II: 129; СлРЯ XI-XVII вв. 7: 216]; 'сосуд в роде чаши с ручкой, удобный для черпания' [Вельтман 1860: 122]. Заимствовано из лит. káušas 'уполовник, ковш, большая ложка' наряду c kiáušas 'череп, твердая оболочка, чаша', лтш. kaûss 'череп, чаша, ложка', которые родственны др.-инд. kốșas 'сосуд, бочка' [Фасмер II: 273]. Форма ковша могла быть не только традиционно округлой, на- 
подобие черпака, но и ладьевидной [Кулешов 2008: 254]. Ковши разделялись на выносные и питие (см. ниже)

(ковиъ Великии зол(о)тъ гладъкии [Гр. 16]; два ковша золоты по двъ гривенки [Гр. 36]; ковиъ серебрен с вгонцем [Гр. 221]; два ковиа золоты [Гр. 276]; ковиъ золот [Гр. 406]; ковиь велик серебрен [Гр. 406]; ковшъ болиои, венец оу нег(о) писан золочон, имл кн(А)зА Бориса Васильевича, а на полке лит звгьрь и оузоръ [Гр. 411]; ковиъ болшои, венец оу нег(о) писан, има Григор(ъ)па Васил(ъ)евича Морозова [Гр. 411]; ковиъ гладок, а внутри писано има Еоуөим(ъ)ево [Гр. 412]; ковиъ гладокъ, венеи, писан золочон, има Горонтьла митрополита, а на полке двг рыбки золочоны [Гр. 412]; став плт(ь) ковиов, ито мнгь дал кназ(ъ) Велики Василеи, а вениы оу них писаны, имл великог(о) кн(А)за Васил(в)п ИВановича Всег Р8си, а въсс8 в них полдр8гонатиаты гривенки и два золотника [Гр. 412]; ковиъ грановит через гран(в) золочон, венеи писан золочон, имл Өеюөила, вл(a) д(ы)ки новогородикково, а полка скан (ъ)ю дъљлана [Гр. 412]; десат(ъ) ковиов, Венцы оу них писаны, има кн(А)за Дмитрега Ивановича [Гр. 413]).

КОВШ вынОСНОЙ - имел большой размер и употреблялся для выноса из погреба напитков и соленых, сыченых и квашеных овощей и плодов [Вельтман 1860: 122-123]. См. выше КОВШ

(...а выносных ковшов: ковшъ гладок, а внутри в кр8гв писаны слова, имл Васил(ь)п Флександровича [Гр. 411-412]; ковщъ, венеи писан золочон, имя Казимира корола [Гр. 412]; ковиъ, венеи писан золочон, имл пана Михаила Кезгаиловича, ито мнгъ дал кназ(ъ) велики Василеи, а полка на четыре оуглы скан(ъ)ю делана, а внутри клеино с өиниөтом [Гр. 412]).

КОВШИК (КОВШИКЪ) - уменьшит. от КОВШ [СлРЯ XI-XVII вв. 7: 216] (два ковиика золоты, шдин с камышком да з жемчюжки [Гр. 302]; ковиик на стогание венеи золочон, скан(ъ)ю дъљан, а на полке нащока скан (ъ)ю же дглана [Гр. 412]).

МУШЕРМА/МУШОРМА/МИШУРМА (МУШОРЪМА - Срезн. II: 200) ‘братина с носком' [СлРЯ XI-XVII вв. 9: 323]

(м8иорма с носком и с р8когад(ъ)ю, венцы и звъри золочоны гладки, а на покрышке въ кр8г8 на өиниөте писано имл кн(А) за Дмитрега Ивановича [Гр. 413]).

ОВКАЧ (ОВКАЧЬ) ‘ковШ?' [СлРЯ ХI-XVII вв. 12: 223]

(2 овкача золота [Гр. 7]; 2 овкача зол(о)та [Гр. 16]).

ОВКАЧИК (ОВКАЧИКЪ) - УмеНЬШИТ. от ОВКАЧ [СлРЯ ХІ-XVII вв. 12: 223] (овкачикъ золотъ [Гр. 16]).

СТАВЕЦ (СТАВЕЦЪ) 'сосуд, сходный с братиной или чашей, обычно с крышкой; использовался в качестве столовой посуды, для хранения и перевозки жидких продуктов, в качестве бытовой меры' [СлРЯ XIXVII вв. 27: 176]; 'миска (деревянная)' [Фасмер III: 742]; уменьшит. от слова СТАВЪ [Срезн. III: 489]

(четыре ставии [Гр. 302]; ставеи, а на нем писано имл кн(А) за ИВана Юрьевича [Гр. 412]; три ставиы, оу Фдново четыре кр8шки писаны золочоны, а оу дв8 венцы писаны, а не золочоны [Гр. 414]; три ж ставиы, оу дв8 погаски писаны золочоны, имА кн(А) зА ИВана Юрьевича, а оу трет(ь)ево погасок писан, а не золочон, имл кн(А) за GНндрга Васильевича [Гр. 414]). 


\section{2. Названия посуды, предназначенной для питья напитков}

ДОСТОКАН/ДОСТАКАН (ДОСТАКАНЪ) 'стакан' [Срезн. I: 715; СлРЯ XI-XVII вв. 4: 338]. Др.-русск. название считают заимствованием из тюрк.: ср. чагат. tostakan 'деревянная мисочка', казах. tustayan 'стакан, плошка, черпак'; едва ли правильно производить тюрк. слова из русск. или из лтш. stakans. Не существует также родства со стекло [Фасмер III: 316]

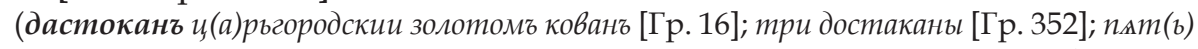
достоканов, а на них по три свитки, да по три крушки, да вензы золочоны [Гр. 413]; n丸m(ъ) достоканов малых, а на них по три венцы да по кр8шк8 писаны золочоны [Гр. 413]; два достокана, оу шдног(о) сверх8 изнутри золочоно, да на середке погас писан золочон, а др8гои с пр8т(ъ)ем, а дв8 пр8тов нгт [Гр. 413]; пАт(ь) достоканов с вершком, шдин на ношках с погски, скан(ь)ю делан, а четыре гладки, венцы золочоны [Гр. 413]; пат(в) достоканов оуголчатых с вериком же, венцы золочоны, а внутри клеино с өиниөтом, писаны слова [Гр. 413]).

ДОСТОКАНЕЦ (ДОСТОКАНЕЦЪ) - УМеНЬШИТ. от ДОСТОКАН [СлРЯ XI-XVII вв. 4: 338]

(два достоканиа, Фдин гладок, а оу др8гово на середке погскк золочон [Гр. 413]).

КОВШ ПИТИЙ/ПИТЬЕВОЙ - индивидуальная посуда для напитков. См. выше КОВШ

(тритцат(ь) и деват(ь) ковиов пит(ъ)их розни [Гр. 412]; сем(ъ) ковиов пит(ъ)их гладких, да два ковиа пит(ь)и гладки, а внутри писаны слова золочоны, имл Михаила Семеновича [Гр. 413]; два ковша пит(в) их, внутри писано имы Өеюөилово [Гр. 413]; сем(ъ) ковиов пит(ъ)их, на днг писано имл Еоуөим(ъ)ево [Гр. 413]).

КУБОК (КУБОКЪ) 'сосуд с крышкой, чаша, кубок' [СлРЯ XI-XVII вв. 18: 102]; 'пузатый сосуд с горлышком' [Фасмер II: 394]. Вероятно, родственно др.-инд. kumbhás, авест. хumba- 'горшок', памирск. kubūn

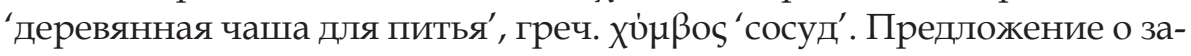
имствовании через нов.-в.-н. Корf 'голова' или прямо из лат. сирра 'кубок' фонетически невозможно; сомнительно также возведение к д.-в.-н. kuofa 'кадка'. Нет основания говорить о происхождении из чагат. köb, köрӥ 'пузатый сосуд’ или тюрк. kub, kup ‘кувшин'. Не существует также связи с праслав. *kъbьlъ 'чан' [Фасмер II: 394]

(кубок хрусталнои, что ми король прислал [Гр. 61]; к8бок серебрннъ на чешвю бить [Гр. 221]; к8бок серебрднғ на косые грани бит [Гр. 221]; три кубки [Гр. 352]; кубок с полкою серебрен золочон, а весу полпеты гривенки и восмъ золотников [Гр. 406]; кубок чеканен с финифтом серебрен жо золочон, а весу четыре гривенки без деслти золотников [Гр. 406]; семнатцат (ъ) кубков золочоных и не золочоных розных спвпыши и с травами и достокановым дглом [Гр. 411]).

РОГ (РОГЪ) 'сосуд, сделанный из рога животного или подобный ему по форме' [Срезн. III: 131; СлРЯ XI-XVII вв. 22: 175-176; Вельтман 1860: 134]

(por [Гр. 352]; por [Гр. 411]). 
ЧАРА 'чаша, чарка' [Срезн. III: 1471]. Считается родственным др.-инд.

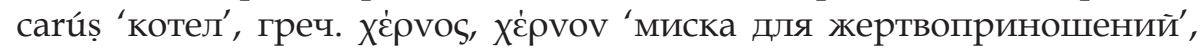
др.-ирл. coire, кимр. pair 'котел', др.-исл. hverr 'котел', hverna 'горшок', haírnei 'череп'. Напротив, другие пытаются объяснить вост.-слав. слова как заимствования из тюрк. и видят источник в тат., алт., вост.-тюрк. с̌аra 'большая чаша', монг. с̌аra [Фасмер IV: 316]

(2 чары золот(ы) [Гр. 8]; чар8 золот8 [Гр. 221]; три ковии да чара [Гр. 351]; чара болшаг, венеи оу нее писан золочон, има кн(А)за ИВана Юрьевича, а въсу В ней тринатцт(ъ) гривенок [Гр. 411]; а походных с8дов чара гладкага, да чара, венеи оу нее писан, а внутри клеино писан звгьрь, а въьс8 В обгих чарах полшестынатиаты гривенки и пАт(ъ) золотников [Гр. 412]).

ЧАРКА - уменьшит. от ЧАРА

(чарка золота [Гр. 276]; три чарки золоты [Гр. 302]; три чарки зблюты [Гр. 310]; Восмь илрок серебраных грановитых з золотом [Гр. 350]; сем(в) чарок глатких, да Фсмаг чарка с полкою [Гр. 352]; дбъ чарки болиих [Гр. 352]; четыре чарки малых [Гр. 352]; тритиат(в) и семь чарок розни, и на мисюрское дъло, а въсв $b$ них дватицат(ь) гривенок и полдеваты гривенки без золотника [Гр. 412]; четыре чарки с полками, а на полках литы оузоры, а венцы изнутри писаны золочоны, а на днг клеино с өиниөтом писано золочоно, да по три рыбки золочоны [Гр. 413]; மдиннатиат(ъ) чарок гладких, Венцы оу них изнутри и на днғ писаны золочоны, им.А кн(А) зА Васил(ъ)га кн(А)жа ИВанова сы)на Юрвевича [Гр. 413]; три чарки ромғики гладки, а на них по четыре крушки, има кн(А) за Дмитрега Ивановича [Гр. 413]).

ЧАША - 1. 'круглый (в виде полушария) сосуд для жидкости'; 2. 'сосуд для питья, чара, чарка'; 3. 'чаша с питьем, питье'; 4. 'потир, чаша для священных даров' [Срезн. III: 1483]. Праслав. с̌аšа, по-видимому, родственно др.-прусск. kiosi 'кубок' из балт. *kiōsē или *kiāsē. Во всяком случае, др.-прусск. слово не могло быть заимствованным из слав. [Фасмер IV: 320].

(2 чаши золоты с женчуги [Гр. 7])

ЧАШКА - уменьшит. от ЧАША [Срезн. III: 1484]

(2 чашки кругльи золоты [Гр. 7]; чашка золота [Гр. 16]).

чуМ (Ч8МЪ) 'ковш' [Срезн. III: 1552]; 'черпак, ковш' [Фасмер IV: 381]. Производится из тат. с̌umус̌ 'посуда для питья', чагат. с̌umс̌а 'черпак', čumuš, čumšuk ‘большая ложка' , кыпч. с̌ömič ‘шумовка' [Фасмер IV: 381] (2 чума золота болиап [Гр. 7]).

ЧУМОК (Ч8МЪКЪ) ‘ковшик' - уменьшит. от ЧУМ [Срезн. III: 1552] (2 чумка золота меньшаг [Гр. 8]).

\section{3. Названия плоской посуды}

БЛЮДЕЧКО - уменьшит. от БЛЮДО (см. ниже) (три блюдечка малые [Гр. 412]).

БЛЮДО ‘блюдо’ [СлРЯ XI-XVII вв. 1: 246-247]; ‘плоский сосуд для подачи пищи' [Вельтман 1860: 113]. Древнее заимствование из гот. biufs, 
род. пад. biudis 'блюдо, миска', также д.-в.-н. biutta 'квашня, улей', нов.-в.-н. Beute 'добыча' от гот. biudan 'предлагать' [Фасмер I: 178]

(3 блюда серьбрьна [Гр. 7]; блюдо серебрьно юздниньскою [Гр. 7]; блюдо серебрьно, а 2 малаг [Гр. 8]; блюдо великон серебрьнок о 4 колия [Гр. 8]; блюдо серебрено великое с колии [Гр. 16]; пмт(ь) блюд [Гр. 302]; суды серебрмные, тритијат(ь) блюд без одног(о) [Гр. 352]; блюдо гладкое, да деслт(ъ) блюд ламаных [Гр. 412]; деслт(ь) блюд, а на них има великог(о) кн(я)зн Ивана Васил(ь)евича всег Рвси в трех кр8шкьх [Гр. 412]; сорок и шесть блюд, а на них на краех по мишенця по выбоичатом8 [Гр. 412]; п九т(ь) блюд, а на них на краех по два мишенияа по выбоччатом8 [Гр. 412]; тритцат(ь) и семь блюд гладких [Гр. 413]; девлт(ь) блюд гладких, а на них на краех по мишенцв по выбойчатом8 [Гр. 413]; два блюда, а оу них на краех имл Еоуөим(ъ)ево [Гр. 413]; два блюда, а на краех оу них оу шдног(о) писано имн великог(о) кн(«)зя Ивана, а оу др8гово писано имм посадника Луки Өедоровича [Гр. 413-414]).

БЛЮДО ГУСИНОЕ ‘блюдо, предназначенное для подачи на стол жареного гуся' [Вельтман 1860: 114]

(два блюда гвсины, மдно гладко, а на др8гом четыре мишени, имА великог(о) кн(А)зА Ивана Васил(ь)евича [Гр. 412]; блюдо гвсино, а оу нег(о) на краех написано в кр8шкљ имл великог(о) кн(я)за Ивана, а въсс8 в нем шесть гривенок без трех золотников [Гр. 413]).

БЛЮДО ЛЕБЕЖЬЕ ‘блюдо, предназначенное для подачи на стол жареного лебедя' [Вельтман 1860: 114]

(блюдо лебеж(ь)е [Гр. 412]).

БЛЮДЦЕ (БЛЮДЦО) 'малое блюдо, parva patina' [Срезн. I: 121]; уменьшит. от БЛЮДО [СлРЯ XI-XVII вв. 1: 248] (см. выше)

(блюдие золото с женчугомь с каменьюмь [Гр. 7]; 2 блюдизи меншии [Гр. 7]).

СКОВОРОДА 'плоский металлический сосуд с загнутыми краями, предназначенный для жарения или печения' [СлРЯ XI-XVII вв. 24: 217]; 'металлическое блюдо, употребляемое для печения или жарения' [Срезн. III: 376]. Праслав. *skovorda, *skovordy, -ъve. Дальнейшее родство неясно. Сравнивают с д.-в.-н. scart-îsan 'котелок, сковорода', ср.-в.-н. scharte ж., schart м., ср. р. Согласный -в- объясняют из ст.-слав. сквара и близких [Фасмер III: 644]

(сковорода серебрена с вениом [Гр. 352]; сковорода, венец, изнутри писан золочон, имА великие кн(я)г(и)ни Марьи, а на р8кога писано и золочоно с өиниөтом [Гр. 412]).

ТАРЕЛЬ (ТАРЂЛЬ) 'плоская круглая посудина' [Срезн. III: 925]. По-видимому, через польск. talerz, чеш. talíŕ ‘тарелка' из ср.-в.-н. talier 'тарелка', бав. taller, ит. tagliere - то же от țagliare 'резать', лат. taliāre - то же [Фасмер IV: 24] (тарьљь [Гр. 412]).

\section{4. Названия глубокой посуды}

МИСА - 1. 'блюдо' [Срезн. II: 153]; 2. ‘большая металлическая или глиняная чаша, миска' [СлРЯ XI-XVII вв. 9: 178]; 3. 'блюдце с поддоном, на которое кладется вынутый из просфоры агнец; дискос' [Срезн. II: 153; СлРЯ XI- 
XVII вв. 9: 178]. Фасмер [II: 627] считает слово миса старым заимствованием из народно-лат. mēsa 'стол', лат. mēnsa - то же; возможно, через гот. mēs cp. p. 'стол', восходящее к тому же источнику. Согласно названному автору, в пользу данной этимологии говорят многочисленные случаи заимствования названий сосудов из герм. в слав.

(двънатиат(ь) мис серебрнных [Гр. 276]; плть мис [Гр. 352]; дватиат(ь) мис и юдна миса, на деслти мисах на краех по три митени, имл великог(о) кн(А)зн Ивана Васил(ь)евича всег Р8си, а на шти мисах на краех по мишения по выбоичатом8, а на дв8 мисах имл Еоуөим(ъ)ево, ана дв8 ж мисах по мишени по литовском8, а миса глад(ка) га, а въсс8 въ дватицати и в однои мисе сто гривенок и три гривенки безо шти золотников [Гр. 412]; миса болшаг [Гр. 412]; миса, на днг оу нее писано имл Васил(ь)га Gлександровича [Гр. 413]; миса, а оу нее на крае два крушка, имх Еоуөим(ь)ево [Гр. 413]; миса, а оу нее по краем в трех мғстех има Ивана Gөоносова [Гр. 413]; три мисы, а оу них на краех по мишенив по выбойчатом8 [Гр. 413]; миса гладкаг [Гр. 413]).

РАССОЛЬНИК/РОССОЛЬНИК (РОСОЛЬНИКЪ) 'глубокое блюдо' [Срезн. III: 168]; 'сосуд в виде глубокого блюда, блюдца, вазы, иногда на ножке с поддоном' [СлРЯ XI-XVII вв. 20: 60] (росолник [Гр. 412]; росолник, а на нем четыре крушки, а в них писано имА кн(А)жо Дмитреево Ивановича [Гр. 414]).

\section{5. Названия посуды для подачи на стол специй и приправ}

ГОРЧИШНИК 'сосуд для горчицы' [СлРЯ XI-XVII вв. 4: 97]

(деват (ъ) горчишников, семь гладких, а оу дв8 на краех по три мишенцы, а $b$ них писано има великог(о) кн(А) за Иваново [Гр. 414]).

ПЕРЕЧНИЦА - ср. совр. перечница [СлРЯ XI-XVII вв. 14: 305]

(перечница [Гр. 352]; перечница с вершком, а вершок на неи скан(ь)ю дглан золочон, а на днг три мишени золочоны [Гр. 412]; двг перечницы на стоганиех с вершки, через грань золочоны, с 8зором [414]; двг перечницы на стогниех с вершки, шдна через грань золочона, а др8гага гладкаг, погсок скан(ь)ю дълан [Гр. 414]).

СОЛОНИЦА 'сосуд для подачи на стол соли, солонка' [СлРЯ XI-XVII вв. 26: 136; Срезн. III: 461]

(три солоницы, двг солоницы на зверкгох с вершки, по оузором писаны и золочоны, а солоница с вериком дъялана с өиниөтом скан(z)ю, золочона, а на неи люди литы [Гр. 412]; двъ солоницы изламаны [Гр. 412]; четыре солоницы на стоганцех, оу Фдное венеи писан золочон, има великог(о) кн(А)за Ивана, а оу др8гие венеи писан золочон, а на днть три крвики золочоны, а $b$ одном крушк8 писано имл кн(А)жо Андрғево, а оу дву венцы писаны, а не золочоны, оу шдное имл великог(о) кн(А)за Ивана, а оу др8гие: „при славе б8ди смирен" [Гр. 414]; солоница двоичата с п8пышы [Гр. 414]).

СОЛОНКА 'сосуд для подачи на стол соли' [СлРЯ XI-XVII вв. 26: 136] (солонка болиага, да двъ малых глатких [Гр. 352]).

УКСУСНИЦА 'сосуд для подачи на стол уксуса'; производное от 8кс8съ 'окислившееся вино' [Срезн. III: 1193]

(оуксусница [Гр. 352]; оуксуснииа чеканена на стоганце с рукогд(ъ)ю и с носком [Гр. 412]; двъ оуксвснищы на стоганцех с верики, и с носки, и с р8когад(ъ)ми, через грань золочоны, с 8зором [Гр. 414]). 


\section{6. Названия столовых приборов}

ЛОЖКА - ср. совр. ложка [Срезн. II: 43; СлРЯ ХI-XVII вв. 8: 274]

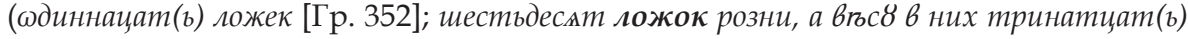
гривенок [Гр. 412]; патдесат ложок розни, а вгос8 в них десат(ь) гривенок без десати золотников [Гр. 414]).

НАЛИВКА 'черпак, ковш' [СлРЯ XI-XVII вв. 10: 135] (бадьг серебрена с наливкою серебреною..., с каменьемъ [Гр. 16]).

ЧЕРПАЛЦО - Производное от ЧЕРПАЛО (ЧЬРПАЛО) 'Ковшь, чаша' [Срезн. III: 1567] (черпалцо [Гр. 413]).

\section{7. Названия прочих столовых принадлежностей}

СЕРЕБРЕНИК (СЕРЕБРЕНИКЪ, СЕРЕБРЯНИКЪ) 'сосуД ДЛЯ УМЫванИЯ, рукомойник' [СлРЯ XI-XVII вв. 24: 81; Вельтман 1860: 131] (серебреник [Гр. 352]).

ШАНДАМ (ШАНДАЛЬ, ШАНДАМЪ, ШАНДАНЪ) ‘подсвечник' [Срезн. III: 1581]. Фасмер [IV: 404] считает шандал, шандан заимствованными из тюрк., ср. тур., тар. šamdan 'подсвечник', тат. šandal. Произведение из франц. chandelier 'подсвечник' опровергается более ранними свидетельствами

(деслт(в) шандамов серебрдных [Гр. 414]).

\section{8. Названия настольных украшений}

\section{СЕРЕБРЯНЫЕ СТАТУЭТКИ И ФИГУРКИ ЖИВОТНЫХ, СМ.:}

(Да семнатцат(ь) кубков золочоных и не золочоных розных с пвпыши и с травами и достокановым дълом, што мнг давал отець наш, кнмз(ь) велики Иван, и которые мнго давал кнлз(ъ) велики Василеи. Да воль, да чолнъ, да куръ. А въсс8 в кубкех, и в воль, и в квре, и в чолнв восмьдесат гривенок и шесть гривенок. [Гр. 411]).

Как видно, применяемые Рюриковичами праздничная посуда и столовые принадлежности отличались искусным ювелирным исполнением и изящной отделкой деталей. Они использовались во время пиршеств и торжественных застолий для демонстрации престижа княжеского рода. Обильная еда и напитки сервировались на стол в роскошных сосудах, подчеркивающих высокий социальный и имущественный статус хозяев.

Данные изученных источников подтверждают наблюдения Александра Фомича Вельтмана [1860: 115, 122] о том, что на ковшах, братинах, блюдах и прочей металлической столовой посуде почти всегда вырезались надписи, преимущественно коммеморативного характера, содержащие имена их владельцев - князей, священников, бояр. Упомя- 
нутый автор обращает также внимание на существование оборота золота и серебра в изделиях на Руси. Золотая и серебряная посуда - в основном чаши, кубки, блюда - очень часто использовалась в качестве даров [Вельтман 1860: 126]. При употреблении посуды с такого рода метками во время торжественных застолий оживала память об их первоначальных владельцах, см.:

(ковиъ болшои што мнг дал ег(о) кнлз(ъ) Велики Василеи, а Венец, писан золочон, имл Еоуеөим(ъ)га Вл(а)д(ы)ки новогородиково, а въ венциг четыре кр8ги, а в них писаны ц(а)рства, а на полке шбразина золочона, а вкруг ег венец на проем золочон, а внутри кружок золочон, а В нем три рыбки [Гр. 411]; ковшъ, Венеи писан золочон, имл пана Михаила Кезгаиловича, что мнт дал книз(ъ) велики Василеи, а полка на четыре оуглы скан(ь)ю делана, а внутри клеино с өиниөтом [Гр. 412]; став пат(в) ковиов, ито мнь дал кнлз(ь) Велики Василеи, а Венцы оу них писаны, имл великог(о) кн(А) зА Васил(в)га ИВановича всег Р8си, а вгсс8 в них полдр8гонатцаты гривенки и два золотника [Гр. 412]; двъ братины, што мнь дал кн(А)з(ь) Велики Василеи, а на них по четыре кр8ики золочоны, а 8 них писано имм Великог(о) кн(А)зн Васил(ъ)ево [Гр. 413]).

Подытоживая вышесказанное, стоит добавить, что золотые и серебряные изделия представляли предмет пожалований монастырям, храмам, приближенным боярам. После установления международных отношений России с заграницей правители отдаривали иноземные посольства элементами столовой посуды из расходной казны. Стоит подчеркнуть, что многие из изделий, упомянутых в духовных грамотах представителей династии Рюриковичей, не сохранились до настоящего времени. Согласно Вельтману [1860: 112-114, 127], крупнейшая утрата драгоценностей казны имела место в 1611 и 1612 гг., когда Московская боярская дума должна была содержать польские и литовские войска. В указанный период из-за нехватки денег была предпринята переливка бо́льшей части серебряных сосудов в монеты для удовлетворения польских войск жалованиями. Тогда же многие золотые и серебряные изделия были выданы Думой в залог и никогда не были возвращены.

\section{Библиография}

Вельтман А. Ф. 1860. Московская Оружейная палата, Москва: Типография Бахматова. Забелин И. Е. 1895. Домашний быт русского народа в XVI и XVII cm., т. 1: Домашний быт русских изарей $b$ XVI и XVII cm., Москва: Товарищество типографии А. И. Мамонтова. Кулешов А. Г. 2008. Посуда в северодвинском застолье, [в:] А. С. Каргин (ред.), Традиционное русское застолье. Сборник статей, Москва: Государственный республиканский центр русского фольклора, с. 250-257.

Словарь ювелирных терминов, электронный ресурс: http:/ /www.jevel.ru/glossary/list. html (доступ 27.09.2017). 
Терновская О. А., Толстой Н. И. 1995. Братчина, [в:] Н. И. Толстой (ред.), Славянские древности. Этнолингвистический словарь в пяти томах, т. 1, Москва: Международные отношения, с. 256-257.

Хренов Н. А. 2008. Застолье $b$ контексте ритуала, [в:] А. С. Каргин (ред.), Традиционное русское застолье. Сборник статей, Москва: Государственный республиканский центр русского фольклора, с. 272-292.

Brzozowska-Krajka A. 1998. "Kto popija i pojada, to mu się dobrze układa”. Ludowa etykieta konsumpcyjna, [в:] P. Kowalski (ред.), Oczywisty urok biesiadowania, Wrocław: Towarzystwo Przyjaciół Polonistyki Wrocławskiej, c. 77-84.

Gradowski M. 1980. Dawne złotnictwo: technika i terminologia, Warszawa: Państwowe Wydawnictwo Naukowe.

Hrynkiewicz-Adamskich B. 2018. Драгоценности Рюриковичей по письменным памятникам (элементы одежды), „Studia Rossica Posnaniensia” XLIII, с. 77-111.

Kempiński A. M. 1993. Stownik mitologii ludów indoeuropejskich, Poznań: Kantor Wydawniczy SAWW.

Malinowski B. 1957. Życie seksualne dzikich w pótnocno-zachodniej Melanezji: mitość, matżeństwo i życie rodzinne u krajowców z Wysp Triobranda Brytyjskiej Nowej Gwinei, tłum. A. Waligórski, J. Chałasiński, Warszawa: „Książka i Wiedza”.

Veblen T. 2008. Teoria klasy próżniaczej, tłum. J. Frenzel-Zagórska, Warszawa: Warszawskie Wydawnictwo Literackie Muza SA.

Zadrożyńska A. 1988. Powtarzać czas początku, cz. 2: O polskiej tradycji obrzędów ludzkiego życia, Warszawa: Wydawnictwo Spółdzielcze.

\section{Список используемых сокращений}

Гр. - Бахрушин С. Б. (ред.). 1950. Духовные и договорные грамоты великих и удельных князей XIV-XVI bb., Москва-Ленинград: Издательство Академии Наук СССР.

Даль - Даль В. И. 1881-1882 (1981-1982). Толковый словарь живого великорусского наречия, т. I-IV, Москва: Русский язык.

СлРЯ XI-XVII вв. - Словарь русского языка XI-XVII вb. 1975-2015, вып. 1-30, Москва: Наука.

Срезн. - Срезневский И. И. 1893-1912. Материалы для словаря древнерусского языка, т. I-III, Санкт-Петербург: Типография Императорской Академии Наук.

Фасмер - Фасмер М. 1986. Этимологический словарь русского языка, т. I-IV, Москва: Прогресс. 
